\title{
Toxicity of Extracellular Products of Vibrio anguillarum
}

\author{
Hiroki INamura, Kiyokuni Muroga and Toshihiro NaKaI \\ Faculty of Applied Biological Science, Hiroshima University, \\ Fukuyama, 720 Japan
}

(Received March 17, 1984)

\begin{abstract}
Vibrio anguillarum produced heat labile $\left(70^{\circ} \mathrm{C}, 10 \mathrm{~min}\right)$ exotoxin lethal to goldfish, Japanese eel, ayu and mouse when injected. The extracellular products (ECP) from cellophane plate cultures (nutrient agar or $\mathrm{BHI}$ agar) at $20^{\circ} \mathrm{C}$ or $25^{\circ} \mathrm{C}$ for $18-36 \mathrm{~h}$ were toxic, but not in $24 \mathrm{~h} \mathrm{BHI}$ broth culture at $25^{\circ} \mathrm{C}$. No lethal endotoxin was detected in filtrate of sonicated cells or heated cells obtained from cellophane plate culture. The lethal dose of the crude ECP from a high virulent strain was approximately $15 \mu \mathrm{g}$ protein/g fish (goldfish).

Proteolytic activity of ECP, which was measured by using azocasein as reaction substrate, was recognized to coexist together with lethal toxicity. When virulent strains were compared with low virulent strains, the production of the lethal exotoxin and protease well correlated with the virulence.
\end{abstract}

Vibrio anguillarum is a well-known fish pathogen to cause vibriosis in salmonid and other fishes in the world (ANDERson and CONROY, 1970; Evelyn, 1971). This organism is seriously considered as a pathogen of vibriosis in cultured ayu (Plecoglossus altivelis) in Japan (MurogA and EguSA, 1967; Kusuda et al., 1979). Recently, as in the case of salmonid fishes, promising results of the vaccination experiments against ayu vibriosis have been reported (ITAMI and KuSUDA, 1978; KuSUda et al., 1978; NAKAJIMA and ChiKahata, 1979).

However, few works have been carried out on the pathogenicity of the bacterium, compared with other fish pathogens such as Aeromonas hydrophila (Allan and Stevenson, 1981; Thune et al., 1982a, b) and A. salmonicida (SAKAI, 1977; Cipriano et al., 1981; Ellis et al., 1981; SHIEH, 1982). It has been reported that virulent strains of $V$. anguillarum habor a specific plasmid class (Crosa et al., 1977, 1980) and this plasmid specifies an efficient iron-sequestering system (CrosA, 1980). Various toxic factors such as hemolysin, cytotoxin, hemagglutinin, resistance to serum bactericidal activity and adhesion to the host cell were investigated in relation to the virulence of the pathogen (MUNN, 1980; Trust et al., 1981; HoRne and BAXENDALE, 1983; Toranzo et al., 1983). But only few informations are available about lethal toxicity of the organism to fish (UMBREIT and TrIPP, 1975).
In this paper, we describe the lethal toxicity to fish and proteolytic, hemolytic and hemagglutinating activities of the extracellular products (ECP) of $V$. anguillarum.

\section{Materials and Methods}

\section{Bacteria}

Vibrio anguillarum strains ATCC-19264 isolated from cod (Gadus callarias) by BAGGE and BAGGE (1956) and PT-81049 from diseased ayu were used in this study. Both these strains belong to serotype J-O-1 (Ezura et al., 1980) and were highly virulent to ayu, the $\mathbf{L D}_{50}$ being less than $10^{2}$ cells/fish. In addition to these, 6 strains of $V$. anguillarum isolated from ayu, coho salmon (Oncorhynchus kisutch), Japanese eel (Anguilla japonica), yellowtail (Seriola quinqueradiata) and red seabream (Pagrus major) were used to compare the lethal toxicity of their ECP to goldfish (Carassius auratus). One of these strains belongs to $\mathrm{J}-\mathrm{O}-1$ and the rest to $\mathrm{J}-\mathrm{O}-3$.

\section{Preparation of ECP and sonicated cell extract}

The extracellular and the intracellular products of $V$. anguillarum were prepared using the following cellophane plate technique (LiU, 1957). Sterile sheets of cellophane were placed on the surface of agar plates and inoculated by spreading $0.2 \mathrm{~m} l$ of a preculture of $V$. anguillarum with a sterile glass rod. After $24 \mathrm{~h}$ incubation at $25^{\circ} \mathrm{C}$, 
grown cells were washed off the cellophane sheet with $4 \mathrm{~m} l$ of $0.01 \mathrm{M}$ phosphate-buffered saline (PBS: pH 7.0). This cell suspension $(200 \mathrm{mg} / \mathrm{m} l)$ was centrifuged at $12,000 \mathrm{rpm}$ for $20 \mathrm{~min}$, and the supernatant obtained was sterilized by means of $0.45 \mu \mathrm{m}$ membrane filter, and some portions were diluted to $1 / 2$ or heated at $100^{\circ} \mathrm{C}$ for $15 \mathrm{~min}$. The precipitated cells were washed three times with PBS, and re-suspended in PBS at a concentration of $200 \mathrm{mg} / \mathrm{ml}$. The washed cell suspension was also divided into three parts: one was sonicated (Kubota Insonater Model $200 \mathrm{M}$ ) and filtered $(0.45 \mu \mathrm{m}$ membrane filter), another was heated at $100^{\circ} \mathrm{C}$ for $15 \mathrm{~min}$, a third was diluted to $1 / 200$.

In order to compare the lethal toxicity of each preparation from brain heart infusion (BHI) agar (Eiken) culture, each $0.1 \mathrm{~m} l$ was inoculated intraperitoneally to goldfish.

\section{Culture conditions}

The toxicity of ECP of a cellophane plate culture and a liquid shaking culture were compared using $\mathrm{BHI}$ agar and $\mathrm{BHI}$ broth as culture media. After $24 \mathrm{~h}$ incubation at $25^{\circ} \mathrm{C}$, the supernatant fluid from the plate culture was obtained by the above-mentioned method and from the broth culture by centrifugation and filtration. The supernatant of broth culture was concentrated in a cellulose tube applying polyethylene glycol 20,000 (Katayama Chemical Co.) to the equivalent concentration $(200 \mathrm{mg} / \mathrm{m} l)$ to that of the supernatant of plate culture. Sterile and concentrated BHI broth and sterile PBS were also injected to goldfish.

The differences in exotoxin production with different culture media, incubation period and temperature, and $\mathrm{pH}$ of the medium were also investigated by using cellophane plate cultures.

\section{Test animals}

In most of the experiments, goldfish, 3 to $6 \mathrm{~cm}$ in body length and 3 to $9 \mathrm{~g}$ in weight, were injected intraperitoneally with $0.1 \mathrm{ml}$ of each preparation. A group of 5 or 10 fish was used for each preparation and observed for one week at about $20^{\circ} \mathrm{C}$. Japanese eel, ayu and mouse were also used to compare the susceptibility to the exotoxin.

Assays

Proteolytic activity of ECP was assayed by a modification of the method described by KREGER and Griffin (1974). The reaction mixture containing $0.5 \mathrm{~m} l$ of azocasein (Sigma Chemical Co.) solution $(5 \mathrm{mg} / \mathrm{ml}$ of $0.2 \mathrm{M}$ tris(hydroxymethyl) aminomethane-hydrochloride at $\mathrm{pH} 8.0), 0.4 \mathrm{~m} l$ of distilled water and $0.1 \mathrm{~m} l$ of each sample solution was incubated at $25^{\circ} \mathrm{C}$ for $20 \mathrm{~min}$. The reaction was stopped by addition of $3.5 \mathrm{ml}$ of $5 \%$ trichloroacetic acid, the precipitate was removed by centrifugation at $3,000 \mathrm{rpm}$ for $5 \mathrm{~min}$, and $4.5 \mathrm{~m} l$ of $0.5 \mathrm{M} \mathrm{NaOH}$ was added to the supernatant fluid. The proteolytic activity of each sample was measured as absorbance at $440 \mathrm{~nm}$ $\left(\mathrm{A}_{440}\right)$

Hemolytic activity was determined using a modification of the method described by BERNHEIMER and Avigad (1974). Sheep erythrocytes were washed several times by centrifugation at 2,500 rpm for $5 \mathrm{~min}$ using $0.02 \mathrm{M}$ Trishydrochloride at $\mathrm{pH} 8.0$, and re-suspended to a density which gave an absorbance of 0.8 at $540 \mathrm{~nm}$ when completely lysed with an equal volume of sodium dodecyl sulfate $(0.025 \%)$. This standard sheep erythrocyte suspension and an equal volume of each sample were mixed, and incubated at $25^{\circ} \mathrm{C}$ for $1 \mathrm{~h}$. The $\mathrm{A}_{\overline{5} 40}$ of the supernatant was measured with a spectrophotometer. One unit of hemolysin activity was defined as an amount of the sample which gave an absorbance of 0.4 at $540 \mathrm{~nm}$.

Hemagglutinating titer was also determined by serial two-fold dilution of samples in microtiter plates with the standard sheep erythrocyte suspension. The mixture was incubated at $25^{\circ} \mathrm{C}$ for $2 \mathrm{~h}$, then placed at $4^{\circ} \mathrm{C}$ overnight, and the titer was read.

\section{Heat-inactivation kinetics}

The stability. of the lethal toxin to goldfish and the protease of ECP were assayed after heating the samples at 30 to $100^{\circ} \mathrm{C}$ for $10 \mathrm{~min}$.

\section{Results}

\section{Lethal toxicity of ECP}

Table 1 shows the result of the experiments on the lethal toxicity of each preparation from the cellophane plate (BHI agar) culture of $V$. anguillarum ATCC-19264 strain. The experiments were performed twice using different lots of fish and 
Table 1. Lethal toxicity of various preparations of Vibrio anguillarum (ATCC-19264) to goldfish [cellophane plate technique-BHI agar at $25^{\circ} \mathrm{C}$ for $24 \mathrm{~h}$ ]

\begin{tabular}{cccc}
\hline \multicolumn{1}{c}{ Injection materials } & $\begin{array}{c}\text { Expt. } \\
\text { No. }\end{array}$ & $\begin{array}{c}\text { Mortality (\%) } \\
\text { (died/tested) }\end{array}$ & $\begin{array}{c}\text { Mean time to } \\
\text { death (hours) }\end{array}$ \\
\hline $\begin{array}{c}\text { Supernatant fluid }(200 \mathrm{mg} / \mathrm{m} l)^{*} \\
\text { A. Undiluted supernatant }\end{array}$ & 1 & $90(9 / 10)$ & 25 \\
B. 2-fold diluted supernatant & 2 & $100(10 / 10)$ & - \\
C. Heated $\left(100^{\circ} \mathrm{C}, 15 \mathrm{~min}\right)$ supernatant & 1 & $0(0 / 10)$ & - \\
Washed cells $(200 \mathrm{mg} / \mathrm{m} l)$ & 1 & $0(0 / 10)$ & - \\
D. Filtrate of sonicated cells & 2 & $0(0 / 10)$ & - \\
E. Heat-killed cells & 1 & $0(0 / 10)$ & - \\
Control & 2 & $0(0 / 10)$ & $0(0 / 10)$ \\
F. Live cells $(1 \mathrm{mg} / \mathrm{m} l)$ & 1 & $0(0 / 10)$ & 17 \\
G. Sterile PBS & 2 & $100(10 / 10)$ & 17 \\
\end{tabular}

Goldfish were injected intraperitoneally with $0.1 \mathrm{~m} l$ of each preparation and maintained at $22.4-24.8^{\circ} \mathrm{C}$ (Expt. 1), 16.0-18.2 ${ }^{\circ} \mathrm{C}$ (Expt. 2).

* Initial concentration of the cells in suspension.

Table 2. Comparison of the toxicity of the extracellular products (ECP) between plate and liquid cultures of $V$. anguillarum (ATCC-19264)

\begin{tabular}{|c|c|c|c|}
\hline Culture condition & $\begin{array}{l}\text { Goldfish } \\
\text { mortality }(\%)\end{array}$ & (died/tested) & $\begin{array}{l}\text { Mean time to } \\
\text { death (hours) }\end{array}$ \\
\hline $\begin{array}{l}\text { Supernatant from } \\
\text { cellophane plate culture }(200 \mathrm{mg} / \mathrm{ml})^{*} \\
\quad\left(\mathrm{BHI} \text { agar-at } 25^{\circ} \mathrm{C}, 24 \mathrm{~h}\right)\end{array}$ & 90 & $(9 / 10)$ & 22 \\
\hline $\begin{array}{l}\text { Supernatant from } \\
\text { liquid shaking culture }(200 \mathrm{mg} / \mathrm{ml})^{*} \\
\quad\left(\text { BHI broth-at } 25^{\circ} \mathrm{C}, 24 \mathrm{~h} \text { ) }\right.\end{array}$ & 0 & $(0 / 10)$ & - \\
\hline $\begin{array}{l}\text { Control } \\
\text { Sterile PBS }\end{array}$ & 0 & $(0 / 10)$ & - \\
\hline $\begin{array}{l}\text { Control } \\
\text { Sterile BHI broth }\end{array}$ & 0 & $(0 / 10)$ & - \\
\hline
\end{tabular}

Goldfish were injected intraperitoneally with $0.1 \mathrm{~m} l$ of supernatant and maintained at $18.0-19.2^{\circ} \mathrm{C}$.

* Initial or adjusted concentration of the cells.

cultures. The undiluted supernatant fluid (A) killed almost all the goldfish injected $(90-100 \%$ ), but the 2-fold diluted (B) or heated (C) supernatants were not lethal. The filtrate of sonicated cells (D) or heat-killed cells (E) did not show any mortality. In the positive control injected with live cells $(\mathrm{F})$ all fish died but none in the negative control group with sterile PBS (G). These results indicated that the strain produced heat labile exotoxin lethal to goldfish.

\section{Effects of culture condition}

The supernatant fluid from a liquid shaking culture of ATCC-19264 strain did not show any mortality in goldfish (Table 2).

The $24 \mathrm{~h}$ or $48 \mathrm{~h}$ cultures on nutrient agar (NA, Eiken), heart infusion agar (HIA), BHI agar (BHIA), trypticase soy agar (TSA, BBL) and NA 
Table 3. Comparison of the toxicity of ECP from $V$. anguillarum (ATCC-19264) grown on various agar media at $25^{\circ} \mathrm{C}$

\begin{tabular}{|c|c|c|c|c|c|c|}
\hline \multirow{3}{*}{ Medium } & \multicolumn{6}{|c|}{ Incubation time } \\
\hline & \multicolumn{3}{|c|}{$24 \mathrm{~h}$} & \multicolumn{3}{|c|}{$48 \mathrm{~h}$} \\
\hline & $\begin{array}{l}\text { Conc. of cell } \\
\text { suspension } \\
(\mathrm{mg} / \mathrm{m} l)\end{array}$ & $\begin{array}{l}\text { Goldfish } \\
\text { mortality } \\
(\%)\end{array}$ & $\begin{array}{l}\text { Proteolytic } \\
\text { activity } \\
\left(\mathrm{A}_{440}\right)\end{array}$ & $\begin{array}{l}\text { Conc. of cell } \\
\text { suspension } \\
(\mathrm{mg} / \mathrm{m} l)\end{array}$ & $\begin{array}{l}\text { Goldfish } \\
\text { mortality } \\
(\%)\end{array}$ & $\begin{array}{l}\text { Proteolytic } \\
\text { activity } \\
\left(\mathbf{A}_{440}\right)\end{array}$ \\
\hline NA & 89 & $100(5 / 5)^{*}$ & 0.435 & 100 & $100(5 / 5)$ & 0.409 \\
\hline HIA & 158 & $100(5 / 5)$ & 0.432 & 170 & $80(4 / 5)$ & 0.406 \\
\hline BHIA & 249 & $80(4 / 5)$ & 0.402 & 260 & $40(2 / 5)$ & 0.357 \\
\hline TSA & 99 & $100(5 / 5)$ & 0.440 & 109 & $100(5 / 5)$ & 0.403 \\
\hline $\mathrm{NA}+$ skim milk & 96 & $100(5 / 5)$ & 0.440 & 124 & $80(4 / 5)$ & 0.408 \\
\hline
\end{tabular}

Goldfish were injected intraperitoneally with $0.1 \mathrm{~m} l$ of supernatant and maintained at $19.8-21.0^{\circ} \mathrm{C}$.

* Number of fish died/tested.

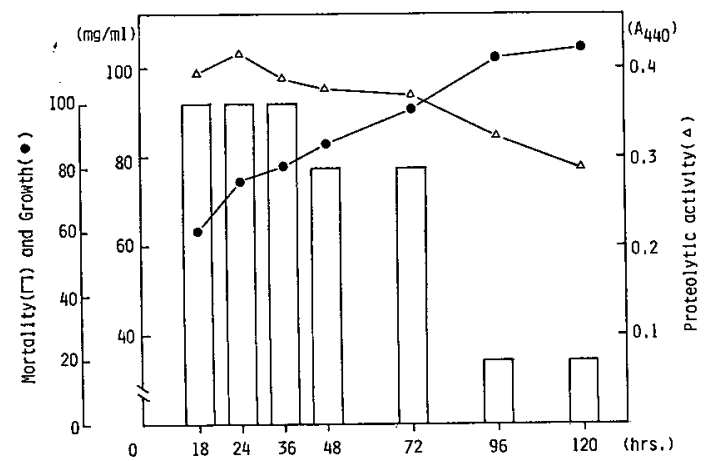

Fig. 1. Effects of incubation period on growth, proteolytic activity and lethal toxicity to goldfish of ECP from $V$. anguillarum (ATCC-19264). (Incubation temperature: $25^{\circ} \mathrm{C}$ )

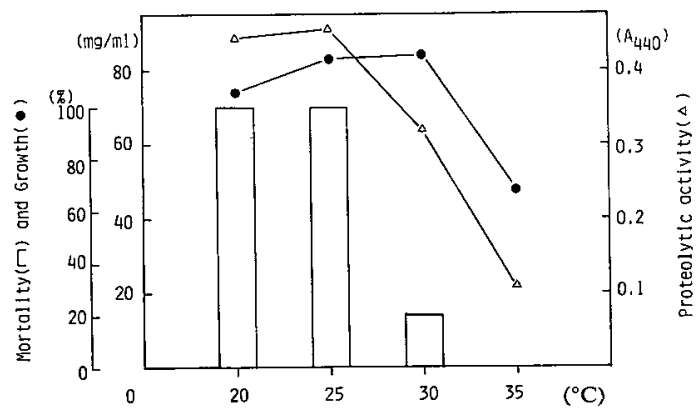

Fig. 2. Effects of incubation temperature on growth, proteolytic activity and lethal toxicity to goldfish of ECP from $V$. anguillarum (ATCC-19264). (Incubation period: $24 \mathrm{~h}$ )

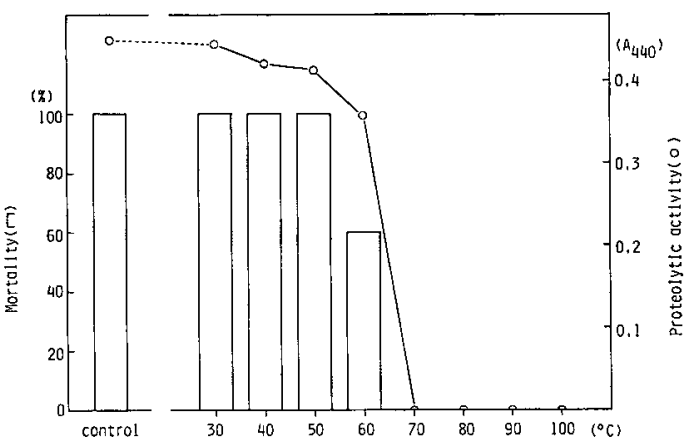

Fig. 3. Stability of extracellular protease and lethal toxicity to goldfish: Heat-inactivation kinetics at $30-100^{\circ} \mathrm{C}$ for $10 \mathrm{~min}$.

with $1.5 \%$ (w/v) skim milk at $25^{\circ} \mathrm{C}$ were compared in toxin and protease production by the cellophane plate technique (Table 3). Although the largest amount of cells was harvested on BHIA, ECP of the culture exhibited lower lethal toxicity and proteolytic activity compared with those of other cultures. Hence, the cellophane plate culture on NA was used in later experiments.

Fig. 1 shows the effects of incubation period on proteolytic activity and toxicity to goldfish of ECP of $V$. anguillarum grown on NA at $25^{\circ} \mathrm{C}$. The amount of harvestable cells gradually increased with the prolonged incubation period. On the contrary, the lethal toxicity to fish and proteolytic activity decreased with incubation period. The mortalities of the fish injected with ECP from $18-36 \mathrm{~h}$ cultures were $100 \%$, those of 48 and $72 \mathrm{~h}$ cultures were $80 \%$, whereas 96 and 
Table 4. Lethal toxicity of ECP from $V$. anguillarum to goldfish, Japanese eel, ayu and mouse by i.p. injection

\begin{tabular}{|c|c|c|c|c|c|}
\hline \multirow[b]{2}{*}{$\begin{array}{c}\text { Test } \\
\text { animal }\end{array}$} & \multirow[b]{2}{*}{$\begin{array}{l}\text { Expt. } \\
\text { No. }\end{array}$} & \multicolumn{2}{|c|}{ ATCC-19264 } & \multicolumn{2}{|c|}{ PT-81049 } \\
\hline & & $\begin{array}{c}\text { Mortality } \\
\% \\
\text { (died/tested) }\end{array}$ & $\begin{array}{l}\text { Mean time } \\
\text { to death (hr.) }\end{array}$ & $\begin{array}{c}\text { Mortality } \\
\% \\
\text { (died/tested) }\end{array}$ & $\begin{array}{l}\text { Mean time } \\
\text { to death }(\mathrm{hr} .)\end{array}$ \\
\hline \multirow[t]{2}{*}{ Goldfish } & 1 & $100(10 / 10)$ & 32 & $100(10 / 10)$ & 12 \\
\hline & 2 & $100(10 / 10)$ & 16 & $100(10 / 10)$ & 12 \\
\hline Japanese eel & 1 & $80(4 / 5)$ & 29 & $100(5 / 5)$ & 17 \\
\hline \multirow[t]{2}{*}{ Ayu } & 1 & $0(0 / 10)$ & - & $60(6 / 10)$ & 6 \\
\hline & 2 & $27(3 / 11)$ & 3 & $91(10 / 11)$ & 3 \\
\hline Mouse & 1 & $40(2 / 5)$ & 23 & $80(4 / 5)$ & 3 \\
\hline
\end{tabular}

The ECP were prepared from cultures on BHI agar (Expt. 1) or nutrient agar (Expt. 2) at $25^{\circ} \mathrm{C}$ for $24 \mathrm{~h}$.

Dose Goldfish: $0.1 \mathrm{~m} l /$ fish $(=1.8 \mathrm{~m} l / 100 \mathrm{~g} \mathrm{BW})$.

Japanese eel: $1 \mathrm{ml} / 100 \mathrm{~g} \mathrm{BW}$.

Ayu: $0.5 \mathrm{ml} / 100 \mathrm{~g} \mathrm{BW}$ (Expt. 1), $1 \mathrm{ml} / 100 \mathrm{~g} \mathrm{BW}$ (Expt. 2).

Mouse: $0.2 \mathrm{ml} /$ head $(=0.8 \mathrm{~m} l / 100 \mathrm{~g} \mathrm{BW})$.

Table 5. Comparison of 8 strains of $V$. anguillarum in virulence and production of exotoxin

\begin{tabular}{|c|c|c|c|c|c|c|}
\hline \multirow{2}{*}{$\begin{array}{l}V . \text { anguillarum } \\
\text { strain }\end{array}$} & \multirow[b]{2}{*}{ Source } & \multicolumn{2}{|c|}{ Goldfish mortality (\%) } & \multirow{2}{*}{$\begin{array}{l}\text { Protease } \\
\left(\mathrm{A}_{440}\right)\end{array}$} & \multirow{2}{*}{$\begin{array}{l}\text { Hemolysin } \\
(\mathrm{HU} / \mathrm{m} l)\end{array}$} & \multirow{2}{*}{$\begin{array}{l}\text { Hemag- } \\
\text { glutinin } \\
\text { (titer) }\end{array}$} \\
\hline & & $\begin{array}{c}\text { Live cells } \\
(0.1 \mathrm{mg} / \mathrm{fish})\end{array}$ & $\begin{array}{c}\mathrm{ECP} \\
(0.1 \mathrm{~m} l / \text { fish })\end{array}$ & & & \\
\hline $\begin{array}{c}\text { ATCC-19264 } \\
(\mathrm{J}-\mathrm{O}-1)^{*}\end{array}$ & Cod & 100 & 100 & 0.449 & 0.65 & 16 \\
\hline $\begin{array}{r}\text { PT-81049 } \\
(\mathrm{J}-\mathrm{O}-1)\end{array}$ & Ayu & 100 & 100 & 0.537 & 1.11 & 32 \\
\hline $\begin{array}{r}\text { PT-77129 } \\
(\mathrm{J}-\mathrm{O}-1)\end{array}$ & Ayu & 100 & 100 & 0.495 & 0.89 & 32 \\
\hline $\begin{array}{l}\text { LS-174 } \\
\quad(\mathrm{J}-\mathrm{O}-3)\end{array}$ & Coho salmon & 100 & 90 & 0.434 & 0.66 & 16 \\
\hline $\begin{array}{c}\text { ET-78062 } \\
(\mathrm{J}-\mathrm{O}-3)\end{array}$ & Japanese eel & 90 & 90 & 0.417 & 0.30 & 8 \\
\hline $\begin{array}{l}\text { HT-78001 } \\
\quad(\mathrm{J}-\mathrm{O}-3)\end{array}$ & Yellowtail & 60 & 10 & 0.261 & 0.18 & 4 \\
\hline $\begin{array}{c}\text { MT-78001 } \\
(\mathrm{J}-\mathrm{O}-3)\end{array}$ & Red seabream & 50 & 0 & 0.008 & 0.15 & 4 \\
\hline $\begin{array}{r}\mathrm{RH}-8101 \\
(\mathrm{~J}-\mathrm{O}-3)\end{array}$ & Red seabream & 50 & 0 & 0.028 & 0.26 & 4 \\
\hline
\end{tabular}

The ECP of each strain were made with nutrient agar culture at $25^{\circ} \mathrm{C}$ for $24 \mathrm{~h}$. Goldfish were maintained at $18.3-22.2^{\circ} \mathrm{C}$.

* Serotype.

$120 \mathrm{~h}$ cultures produced low mortalities of $20 \%$. Both lethal and proteolytic activities were also greatly influenced by the incubation temperature (Fig. 2). The $24 \mathrm{~h}$ cultures at 20 and $25^{\circ} \mathrm{C}$ produced exotoxin but when incubated at 30 and $35^{\circ} \mathrm{C}$ the organism produced little amount of exotoxin. On the other hand, the production of the exotoxin was not influenced by $\mathrm{pH}$ of the agar medium within a range from 6 to 9 .

\section{Heat stability of the exotoxin}

The activity of ECP of ATCC-19264 obtained from NA culture at $25^{\circ} \mathrm{C}$ for $24 \mathrm{~h}$ and heated at various temperatures from 30 to $100^{\circ} \mathrm{C}$ for $10 \mathrm{~min}$ is shown in Fig. 3. The heat treatment at $60^{\circ} \mathrm{C}$ for $10 \mathrm{~min}$ reduced both lethal and proteolytic 
activities to some extent, and at $70^{\circ} \mathrm{C}$ both activities were thoroughly lost. At $-20^{\circ} \mathrm{C}$, the activities of the crude ECP were preserved more than five weeks.

\section{Host species susceptibility to the exotoxin}

Susceptibility of goldfish, Japanese eel, ayu and mouse against the exotoxin of two strains (ATCC19264 and PT-81049) of $V$. anguillarum were examined (Table 4). The first experiment was made with BHI agar culture for the 4 species of animals and an additional experiment (Expt. 2) was done with NA culture for goldfish and ayu. Among the three species of fish, ayu seemed to have the lowest susceptibility to the exotoxin, especially to ECP of strain ATCC-19264. Mouse was also susceptible, and the lethal toxicity to the animal was also lost by heating at $100^{\circ} \mathrm{C}$ for $15 \mathrm{~min}$.

\section{Difference in toxin production with strains}

Lethal toxicity of ECP from 8 strains of $V$. anguillarum from various fishes were examined using goldfish as a test animal. In addition, virulence of the live cells, proteolytic, hemolytic and hemagglutinating activities of ECP were compared. All strains were cultured on NA at $25^{\circ} \mathrm{C}$ for $24 \mathrm{~h}$. Among the 8 strains, ATCC-19264, PT-81049, PT-77129, LS-174 and ET-78062 seemed highly virulent from the results of live cell injection, and the virulence of the other 3 strains were lower (Table 5). The lethal and proteolytic activities of ECP of the high virulent strains were higher than those of the low virulent strains. In contrast, hemolysin and hemagglutinin levels of all strains were very low.

\section{Discussion}

From the results of our experiments, it was revealed that $V$. anguillarum strains produced heat labile exotoxin lethal to fishes and mouse, and the production of the toxin correlated with the virulence of the strains tested.

UMBREIT and TRIPP (1975) reported that not only supernatant culture fluid (BHI broth) but also heat-killed cells of $V$. anguillarum ATCC-15 were lethal to goldfish by intraperitoneal injection, and the toxicity of the supernatant fluid was even enhanced by heating at $100^{\circ} \mathrm{C}$ for $15 \mathrm{~min}$.
Our results are different from their results in two points that no endotoxin was detected from our culture and the exotoxin demonstrated in our experiment was heat labile $\left(70^{\circ} \mathrm{C}, 10 \mathrm{~min}\right)$. Moreover, no exotoxin lethal to goldfish was detected from BHI broth culture (Table 2) which was employed by UMBreIT and TRIPP. At present, no reason other than the difference of material strains seems to explain these discrepancies.

The crude ECP of PT-81049 strain exhibited the highest toxicity among the 8 strains tested (Tables 4, 5), and its lethal dose was approximately $80 \mu \mathrm{g}$ protein/one goldfish or $15 \mu \mathrm{g}$ protein/g fish. The $\mathrm{LD}_{50}$ of the crude ECP from $A$. hydrophila was reported $19 \mu \mathrm{g}$ protein/g fish (channel catfish) (Thune et al., 1982b) and the lethal dose $(72 \%$ mortality) of the crude ECP from $A$. salmonicida was $1,400 \mu \mathrm{g}$ protein/fish (Atlantic salmon) or $140 \mu \mathrm{g}$ protein/g fish (SHIEH, 1982). Thus, the level of toxicity of the crude ECP from $V$. anguillarum seemed comparable or superior to those of the aeromonads, and the exotoxin is thought to play an important role in pathogenicity of $V$. anguillarum. Among toxic factors examined in our study, proteolytic activity correlated with lethal toxicity of ECP. A similar relationship was demonstrated in A. hydrophila (THUNE et al., 1982a, b) and A. salmonicida (SAKAI, 1977; SHIEH, 1982). However, Allan and Stevenson (1981) concluded that the lethality of ECP of $A$. hydrophila was associated with hemolytic activity rather than proteolytic activity. MUNN (1980) also reported that hemolysin obtained from $V$. anguillarum culture was lethal to eel.

The role of these toxic factors in pathogenesis of $V$. anguillarum infection should be clarified by further investigations.

\section{Acknowledgment}

A part of this study was supported by a grant from the Fisheries Agency of Japan.

\section{References}

Allan, B. J. and R. M. W. Stevenson (1981): Extracellular virulence factors of Aeromonas hydrophila in fish infections. Can. J. Microbiol., 27, 1114-1122.

Anderson, J. I. W. and D. A. Conroy (1970): Vibrio disease in marine fishes. in A symposium 
of the American Fisheries Society on diseases of fishes and shellfishes (1969, S. F. SNIEszko ed.), Trans. Amer. Fish. Soc. spe. pub. No. 5, 266-273.

BAGGE, J. and O. BAGGE (1956): Vibrio anguillarum as the cause of an ulcerous disease in codfish. Nord. Vet. -Med., 8, 481-492.

Bernheimer, A. W. and L. S. Avigad (1974): Partial characterization of aerolysin, a lytic exotoxin from Aeromonas hydrophila. Infect. Immun., 9, 1016-1021.

CipRIANo, R.C., B.R. GRIFFIN and B.C. Lidgerding (1981): Aeromonas salmonicida: relationship between extracellular growth products and isolate virulence. Can. J. Fish. Aquat. Sci., 38, 13221326.

CROSA, J. H. (1980): A plasmid associated with virulence in the marine fish pathogen Vibrio anguillarum specifies an iron-sequestering system. Nature, 284, 566-568.

Crosa, J. H., L. L. Hodges and M. H. Schiewe (1980): Curing of a plasmid is correlated with an attenuation of virulence in the marine fish pathogen Vibrio anguillarum. Infect. Immun., 27, 897-902.

Crosa, J. H., M. H. Schiewe and S. Falkow (1977): Evidence for plasmid contribution to the virulence of the fish pathogen Vibrio anguillarum. Infect. Immun., 18, 509-513.

Ellis, A. E., T.S. Hastings and A. L. S. Munro (1981): The role of Aeromonas salmonicida extracellular products in the pathology of furunculosis. J. Fish Dis., 4, 41-51.

EVELYN, T.P. T. (1971): First records of vibriosis in Pacific salmon cultured in Canada, and taxonomic status of the responsible bacterium, Vibrio anguillarum.. J. Fish. Res. Board Can., 28, 517525.

Ezura, Y., K. Tajima, M. Yoshimizu and T. KIMURA (1980): Studies on the taxonomy and serology of causative organisms of fish vibriosis. Fish Pathol., 14, 167-179.

Horne, M. T. and A. Baxendale (1983): The adhesion of Vibrio anguillarum to host tissues and its role in pathogenesis. J. Fish Dis., 6, 461-471.

ITAMI, T. and R. Kusuda (1978): Efficacy of a vaccination by spray administration against vibriosis in cultured ayu. Bull. Japan. Soc. Sci. Fish., 44, 1413.

Kreger, A. S. and O. K. Griffin (1974): Physicochemical fractionation of extracellular corneadamaging proteases of Pseudomonas aeruginosa. Infect. Immun., 9, 828-834.

Kusuda, R., K. Kawai, Y. Jo, T. Akizuki, M.
FukUnaGa and N. Kotake (1978): Efficacy of oral vaccination for vibriosis in cultured ayu. Bull. Japan. Soc. Sci. Fish., 44, 21-25.

KusUda, R., H. SAKo and K. KaWaI (1979): Classification of vibrios isolated from diseased fishesI. On the morphological, biological and biochemical properties. Fish Pathol., 13, 123-137.

Liv, P. V. (1957): Survey of hemolysin production among species of pseudomonads. J. Bacteriol., 74, 718-727.

MunN, C. B. (1980): Production and properties of a haemolytic toxin by Vibrio anguillarum. in Fish Diseases. Third COPRAQ-Session (Ed. W. AHNE). pp. 252. Springer-Verlag, Berlin. 69-74.

Muroga, K. and S. EgUSA (1967): Vibrio anguillarum from an endemic disease of Ayu in Lake Hamana. Bull. Japan. Soc. Sci. Fish., 33, 636640.

Nakajima, M. and H. Chikahata (1979): Efficiency of oral and hyperosmotic vaccinations for vibriosis in ayu. Fish Pathol., 14, 9-13.

SAKaI, D. K. (1977): Causative factor of Aeromonas salmonicida in salmonid furunculosis: extracellular ptotease. Sci. Rep. Hokkaido Fish Hatch., 32, 61-89.

SHIEH, H. S. (1982): Lethal toxicity of Aeromonas salmonicida protease to Atlantic salmon. Microbios Letters, 20, 137-139.

Thune, R. L., T. E. Graham, L. M. Riddle and R. L. AMBorski (1982a): Extracellular products and endotoxin from Aeromonas hydrophila: effects on age-0 channel catfish. Trans. Amer. Fish. Soc., 111, 404-408.

Thune, R. L., T. E. Graham, L. M. Riddle and R. L. AMBorsKi (1982b): Extracellular proteases from Aeromonas hydrophila: partial purification and effects on age-0 channel catfish. Trans. Amer. Fish. Soc., 111, 749-754.

Toranzo, A. E., J. L. Barja, R. R. Colwell, F. M. Hetrick and J. H. Crosa (1983): Haemagglutinating, haemolytic and cytotoxic activities of Vibrio anguillarum and related vibrios isolated from striped bass on the Atlantic Coast. FEMS Microbiol. Letters, 18, 257-262.

Trust, T. J., I. D. Courtice, A. G. Khouri, J. H. CRosA and M. H. SChIEWE (1981): Serum resistance and hemagglutination ability of marine vibrios pathogenic for fish. Infect. Immun., 34, 702-707.

Umbreit, T. H. and M. R. TRIPP (1975): Characterization of the factors responsible for death of fish infected with Vibrio anguillarum. Can. J. Microbiol., 21, 1272-1274. 


\title{
Vibrio anguillarum の菌体外産物の毒性
}

\author{
稲 村 浩 樹*・室 賀 清 邦**中井敏 博*
}

(昭和 59 年 3 月 17 日受理)

Vibrio anguillarum がキンギョ，ウナギ，アコおよびマウスを死亡させうる易熱性 (70 $\mathrm{C}, 10$ 分間) の菌 体外毒素を産生することが確かめられ，そのキンギョに対する致死量は $15 \mu \mathrm{g}$ protein/g fish であった。菌体 外産物の毒性は，七ロファンをのせた普通るしくは $\mathrm{BHI}$ 寒天培地を用いて $20^{\circ} \mathrm{C}$ あいは $25^{\circ} \mathrm{C} て ゙, 18$ 時

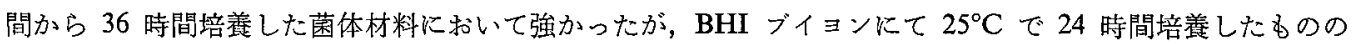
上澄液には認められなかった。セロファンプレート培養した菌体の超音波抽出物や加熱死菌中には致死毒性 をるつ内毒素は検出されなかった。強毒株と弱毒株を比較したところ，前者の菌体外産物の毒性およびアゾ カゼインを反応基質としたプロテアーゼ活性は後者のそれらに比べて高かった。 